\title{
Cognitive Structure Determination of Prospective Science Teacher via Word Association Test
}

\section{Ecir Yilmaz}

Necmettin Erbakan University, Ahmet Keleşoğlu Education Faculty, Chemistry Department, Konya, Turkey. Email:eciryilmaz@erbakan.edu.trTel:+905059022022

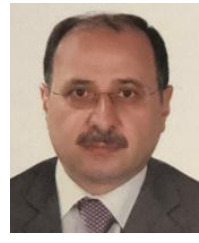

\begin{abstract}
This present study aims to determine the prospective science teachers' cognitive structure about the domain of buffer solution with word-association test. The research was conducted in the spring semester of the academic year of 2018-2019 with a sample of 71 prospective science teachers in the department of science teaching program at a state university in central Anatolian region in Turkey. To be able map the structures, response frequencies were used. Nine of the 71 prospective science teachers are male and the rests are female. This is a qualitative descriptive study. The word-association test contains eight stimulus words to collect data about prospective science teachers' cognitive structure for the domain of buffer solution. The opinions of four instructors who has already taught chemistry III (analytical chemistry in content) course to the prospective science teachers were obtained for the appropriateness of the stimulus words used in the present study. The gained data was analyzed by using response frequency map method. The obtained findings have been discussed on the base of the related studies and some suggestions have been made.
\end{abstract}

Keywords: Cognitive structure, Word-association test, Buffer solution, Prospective science teacher, Frequency mapping, Chemistry teaching.

Citation | Ecir Yilmaz (2019). Cognitive Structure Determination of Prospective Science Teacher via Word Association Test. Asian Journal of Education and Training, 5(3): 422-428

\section{History:}

Received: 3 June 2019

Revised: 5 July 2019

Accepted: 8 August 2019

Published: 18 September 2019

Licensed: This work is licensed under a Creative Commons

Attribution 3.0 License (c))

Publisher: Asian Online Journal Publishing Group
Acknowledgement: The authors would like to acknowledge the technical guidance (guiding about the drawing the cognitive structure map in computer) provided by Assoc.Prof.Dr. Ayşegül DERMAN.

Funding: This study received no specific financial support.

Competing Interests: The author declares that there are no conflicts of interests regarding the publication of this paper.

Transparency: The author confirms that the manuscript is an honest, accurate, and transparent account of the study was reported; that no vital features of the study have been omitted; and that any discrepancies from the study as planned have been explained.

Ethical: This study follows all ethical practices during writing.

\section{Contents}

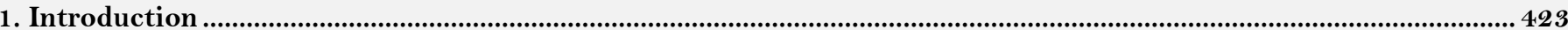

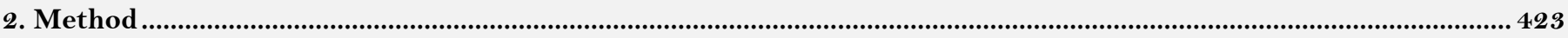

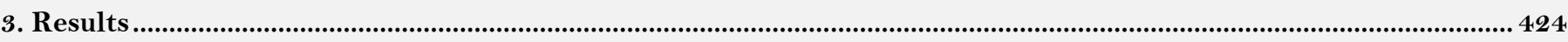

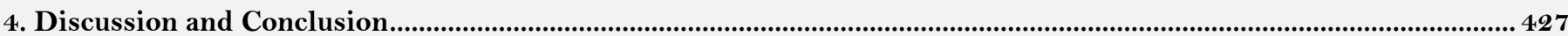

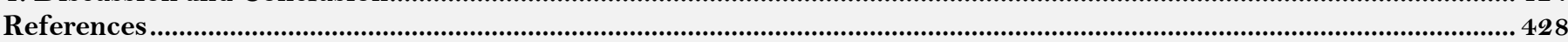




\section{Contribution of this paper to the literature}

This study contributes to existing literature by determining the prospective science teachers' cognitive structure about the domain of buffer solution with word-association test.

\section{Introduction}

Carrying the knowledge to a person's mind and how a person structure this knowledge is one of the main issues that is interest of many education researchers. Constructing the knowledge actively via association of this knowledge with pre-existing knowledge and former experiences is the approach of constructive learning (Bodner, 1986; Anderson, 1992). Learning is a crucial thing for everyone because through learning one can understand and master something and thus can improve his/her ability. The increase in the ability of a person can be seen from the development of knowledge and activeness of the person in forming the knowledge. Learning is the process of the interaction between the existing knowledge in student's mind and what is taught to the student (Posner et al., 1982). Chemistry cannot be learned only through a process of memorization and remembering soundly but students should be able to connect the concepts in chemistry teaching and learning process eventually not to lead to any misconceptions. Misconceptions generally occur due to the lack of student's pre-knowledge of the concept being studied. The lack of students' knowledge might be due to the cognitive structure that students have not well developed. According to Garner (2007) the cognitive structure compares the data sets to process knowledge in understanding the concepts. Students whose cognitive structure has not been well-developed well feel that learning is a burden and an unpleasant activity.

One of the most important topics in chemistry is the buffer solution. To establish a sound and well-developed cognitive structure, students should not only learn about how to calculate buffer $\mathrm{pH}$ but also understand the nature of buffer solution concepts and the importance of buffer conditions in real life. The low learning outcomes of the students are associated with the inability of students in processing knowledge during the learning process or cognitive process of students who have not developed well. Many teachers may assume that the cognitive structure works automatically so that teachers do not directly identify the cause of learning difficulties experienced by the students, and thus, the students' learning outcomes are low because of the cognitive structure of the vain students (Garner, 2007). Teachers should conduct a cognitive structure analysis because the cognitive structure could affect the student's learning process. The cognitive structure can be analyzed using different techniques. Techniques such as multiple choice test, WAT, drawing-writing, concept map, diagnostic tree, conceptual change text and analogy. Based on the above description, the present study tries to determine the cognitive structure of the prospective science teachers by using WAT in teaching buffer solution which is the part of chemistry III course in the fall semester of science teaching program. Not only in the content of chemistry III, but also the subject of buffer takes part in general chemistry II course and its experimental applications. This general chemistry II course is offered in the spring term of the first year. To have knowledge about the students' cognitive structure related to the buffer solution provides some advantages to teachers in terms of instruction (Nakiboglu, 2008; Derman and Eilks, 2016). Analysis of student cognitive structure can be used to know the description of the students' understanding and knowledge about buffer solution. If there is an incorrect or insufficient student understanding of buffer solution then the teacher can find the right solution to overcome the problem. The learning process of the students on buffer solution can provide a learning experience to these students to develop a better cognitive structure. Based on the background that has been described above, the research question of the present study can be identified as follow:

How is the cognitive structure of prospective science teachers based on WAT method about buffer solution?

\section{Method}

Johnson (1967) originally proposed the word association test. Since then, it has been used by many researchers and became a widespread tool in science education studies (Shavelson, 1972; Nakiboglu, 2008; Schizas et al., 2013; Derman and Eilks, 2016). The word association test is a data collection tool used to determine and map the concepts, interrelationships, conceptual structures of cognitive structures related to a phenomenon or subject area in science education researches and has been used by many researchers (Shavelson, 1972; Gunstone, 1980; Bahar and Hansell, 2000; Uzuntiryaki and Geban, 2005; Nakiboglu, 2008; Aydın and Taşar, 2010; Koseoglu and Bayir, 2011; Schizas et al., 2013; Kurt and Ekici, 2013;2013a). The WAT can help us to understand the number of the concepts, the direction and the power of the associations between the concepts in the cognitive structure of learners. The purpose of this study is to analyze the cognitive structure of prospective science teachers by using WAT technique about buffer solution. The research was conducted with a sample of 71 science teaching program students in the spring term at a state university.

\subsection{Data Collection}

In the present study, we collected the data by using WAT technique. A booklet of having eight stimulus words was prepared. These stimulus words are: the solution, buffer solution, acid, buffer capacity, equilibrium concentration, base, analytical concentration and salt. The assurance of the content validity was provided whether the curriculum of the science education program covers the concepts about the topic of buffer solution. Furthermore, the opinions of four instructors who has already taught chemistry III (analytical chemistry in content) course to the prospective science teachers in science teaching program, were obtained for the appropriateness of the stimulus words used in the present study.

The WAT booklets were prepared in a way that participants can only see one stimulus word on two pages. One stimulus word is given in one page and the next page is left blank so the students are not influenced by seeing the relevant stimulus words. The participants then were asked to write as many terms as they can for a given period of time (90 seconds). 


\subsection{Data Analysis}

The total response words were counted and tabulated in Table 2 for each stimulus word. The author used the response frequency map suggested by Nakiboglu (2008). The frequency table and the frequency map were prepared. The direction and the thickness of the arrows were determined according to the frequency table. Thicker the arrow or rectangular box the more frequent the word is. Two types of arrows are designated to show the association. The first one is a continuous and originated from the stimulus words to the response words. The numbers at the right side of these arrows represent the thickness of the arrows. The second type of arrow is a dotted line. These arrows are used to represent the association of the same response word with different stimulus words.

These arrows are also originated from the stimulus words to the response word. The thicknesses of the arrows are represented by the italic number at the right side of the arrows in order to prevent the confusion. The validation of the response words were checked with the content of chemistry III course which is given to the sophomore student in the fall semester. In the context of chemistry knowledge or especially the topic of buffer solution, the unrelated response words were omitted. If the frequency value of the response words was four or less, it is not included in the frequency table. Since the obtained response words are enormous data in number, a sample of the most repeated ones is given in the frequency table see Table 2. For each stimulus word, participants were allowed ninety seconds to write the words in their mind. It took about 12 (90 seconds for each stimulus Word) minutes to complete WAT booklets.

As a tool WAT is used to collect the data about the cognitive structure of the prospective science teachers on the topic of buffer solution. The WAT is a reliable technique used as a procedure for measuring numbers of the concepts, directions and strengths of the association between the concepts (Mervis and Rosch, 1981; Novak and Govin, 1984).

\subsection{Educational Background and Sample}

In Turkey, science teaching is a four-year college program. The program mainly consists of biology, chemistry and physics courses. In the first year of the program, prospective science teachers (PSTs) are given general chemistry I and its applications in the fall semester and general chemistry II and its application in the spring term. General chemistry II course covers the chapter of acids and bases which composed of $\mathrm{pH}$ and $\mathrm{pOH}$ calculation of aqueous solutions, acid-base reactions, titrations, hydrolyses and buffer solutions.

In the fall term of the second year, chemistry III course is taught to the PSTs which cover the all aspects of buffer solutions. According to the outline of the textbook, the topics covered in this course are: a review of elementary concepts of analytical chemistry, gravimetric analysis, titrimetric methods of analysis, solution chemistry, theory of neutralization titration for simple systems, titration curves, buffer solutions, $\mathrm{pH}$ calculations, preparation of buffer solution and buffer capacity. The textbook followed in this course is the analytical chemistry I by Skoog, West and Holler.

Data were collected from 71 PSTs in science teaching program at a state university in the spring term of 2018/2019 academic year. The demographic feature of the PSTs is given in Table 1. All PSTs were expected to know "What is the buffer solution. How it is prepared, how $\mathrm{pH}$ and $\mathrm{pOH}$ values are calculated, what is the buffer capacity and what are the equilibrium and analytical concentration."

\begin{tabular}{c|c|c}
\multicolumn{3}{|c}{ Table-1. Demographic feature of the participants. } \\
\hline Gender & $\mathbf{f}$ & $\mathbf{\%}$ \\
\hline Female & 62 & 87.3 \\
\hline Male & 9 & 12.7 \\
\hline Average age & 20.52 & \\
\hline Total & 71 & 100 \\
\hline
\end{tabular}

\section{Results}

Data obtained from the WAT were analyzed using techniques of number of words and number of responses (Atasoy, 2004; Derman and Eilks, 2016). Unrelated response words such as data, flour, suspension, Qi, Nusret, Kdd, Kc, boiling point, air, gas, gas mixture, iodic, silver-mercury, frequency acid, inhibition, energy, electric current, addition, transformation, fullness, subtraction, soup, white, range, anode and amalgams etc. are not included in the analysis. More than 120 response words were omitted. The result of WAT about buffer solution is encoding. The encoding follows the following format:

(F1), (M2). The letters $\mathrm{F}$ stands for female and $\mathrm{M}$ for male prospective science teachers. The numbers 1 and 2 represent the first and the second student respectively. This representation was used up to the $71^{\text {st }}$ student.

The frequencies of response words for the stimulus word are presented in Table 2 . The correlation between the stimulus and response words was shown using frequency map. Seven different frequency range categories were obtained from the survey and this is given in Figure 1-3. In the frequency map the arrows are originated from the stimulus words and directed to the response words. Each stimulus word was put in a rectangular box. The thickness of the rectangular box is also associated with the number of frequency of that word presented in the box. The thickness of the used arrow was set as the number frequency. The numbers next to the arrows represent the number of frequency of response words. For instance, the thickest arrow is represented as 62 in which word "Base" (a response word) which is associated with the stimulus word "Salt" was repeated 62 times accordingly, it is placed in the first category. Furthermore the thickness of the rectangular boxes was set as the number highest frequency. For example, the thickness of rectangular box of stimulus word "Base" is 53. The same thickness was used for the stimulus word "Base" throughout the frequency map. Same applies for the other stimulus words. 
Table-2. A sample frequency table from WAT data.

\begin{tabular}{|c|c|c|c|c|c|c|c|c|}
\hline \multirow[b]{2}{*}{$\begin{array}{c}\begin{array}{c}\text { Response } \\
\text { words }\end{array} \\
\end{array}$} & \multicolumn{8}{|c|}{ Stimulus words } \\
\hline & Solution & $\begin{array}{l}\text { Buffer } \\
\text { solution }\end{array}$ & Acid & $\begin{array}{c}\text { Buffer } \\
\text { capacity }\end{array}$ & $\begin{array}{c}\text { Equilibrium } \\
\text { concentration }\end{array}$ & Base & $\begin{array}{c}\text { Analytical } \\
\text { concentration }\end{array}$ & Salt \\
\hline Base & 31 & 47 & 26 & 25 & 15 & - & 13 & 62 \\
\hline Acid & 33 & 50 & -- & 26 & 16 & 27 & 13 & 53 \\
\hline $\mathrm{pH}$ & 12 & 33 & 46 & 22 & 6 & 28 & - & 15 \\
\hline Water & 26 & 28 & 8 & 7 & - & 12 & - & 37 \\
\hline Salt & 10 & 31 & 17 & 9 & 5 & 20 & - & - \\
\hline Solution & - & 8 & 7 & 19 & 16 & 7 & 8 & 10 \\
\hline Solute & 41 & 11 & - & 5 & 7 & - & 6 & - \\
\hline Solvent & 42 & 12 & - & - & 6 & - & - & - \\
\hline Reaction & - & 10 & 8 & - & 16 & 7 & 5 & 20 \\
\hline Litmus paper & - & - & 38 & - & - & 30 & - & - \\
\hline Mixture & 42 & 8 & - & - & - & - & - & - \\
\hline Sour & - & - & 44 & - & - & - & - & - \\
\hline Neutral & -- & -- & 9 & -- & -- & 9 & -- & 22 \\
\hline $\mathrm{OH}$ ion & -- & -- & -- & -- & -- & 36 & - & -- \\
\hline $\mathrm{H}$ ion & - & - & 27 & -- & - & -- & - & - \\
\hline Weak base & - & 22 & - & 7 & - & - & - & - \\
\hline Products & -- & - & -- & -- & 21 & -- & -- & - \\
\hline Equilibrium & - & 8 & - & 5 & 3 & - & 5 & - \\
\hline Reactants & - & & -- & - & 20 & - & - & - \\
\hline Strong acid & - & 12 & 6 & 5 & - & -- & - & - \\
\hline Weak acid & - & - & 7 & 5 & 7 & - & - & - \\
\hline
\end{tabular}

Moreover, the stimulus words are also presented in a rectangular box. The thickness of the box for each of the stimulus words is different. The frequency obtained in the survey was classified into three different levels. The first one is high, the second one is moderate and the last one is weak level. The dotted-line arrows are also used to show the association of different stimulus words with the same response word about the buffer solution.

At the highest level in Figure 1, the response word base associated with the stimulus word salt is repeated 62 times. At the $61 \leq f \geq 70$ level, salt was associated only with one word, "Base". The other stimulus words are not associated at this level. At the second level, salt and base are associated 53 times. The word salt is associated with acid and the word base with "hot." At the third level only the words buffer solution, acid and solution are associated. The word buffer solution is associated with two response words, acid and base, the word acid is associated with response word $\mathrm{pH}$ and "sour" and the word solution is associated with four response words, homogeneous, mixture, solvent and solute. At the fourth level (the moderate level), the words salt, base, acid, solution and buffer solution are associated. The stimulus word salt is associated 37 times with the word water. The stimulus word base is associated with 7-14 numbers and $\mathrm{OH}^{-}$ion 36 times on both. The stimulus word acid is associated with the response word litmus paper and 0-7 numbers. At this level, the response words acid, heterogeneous and base are associated with the stimulus word solution.

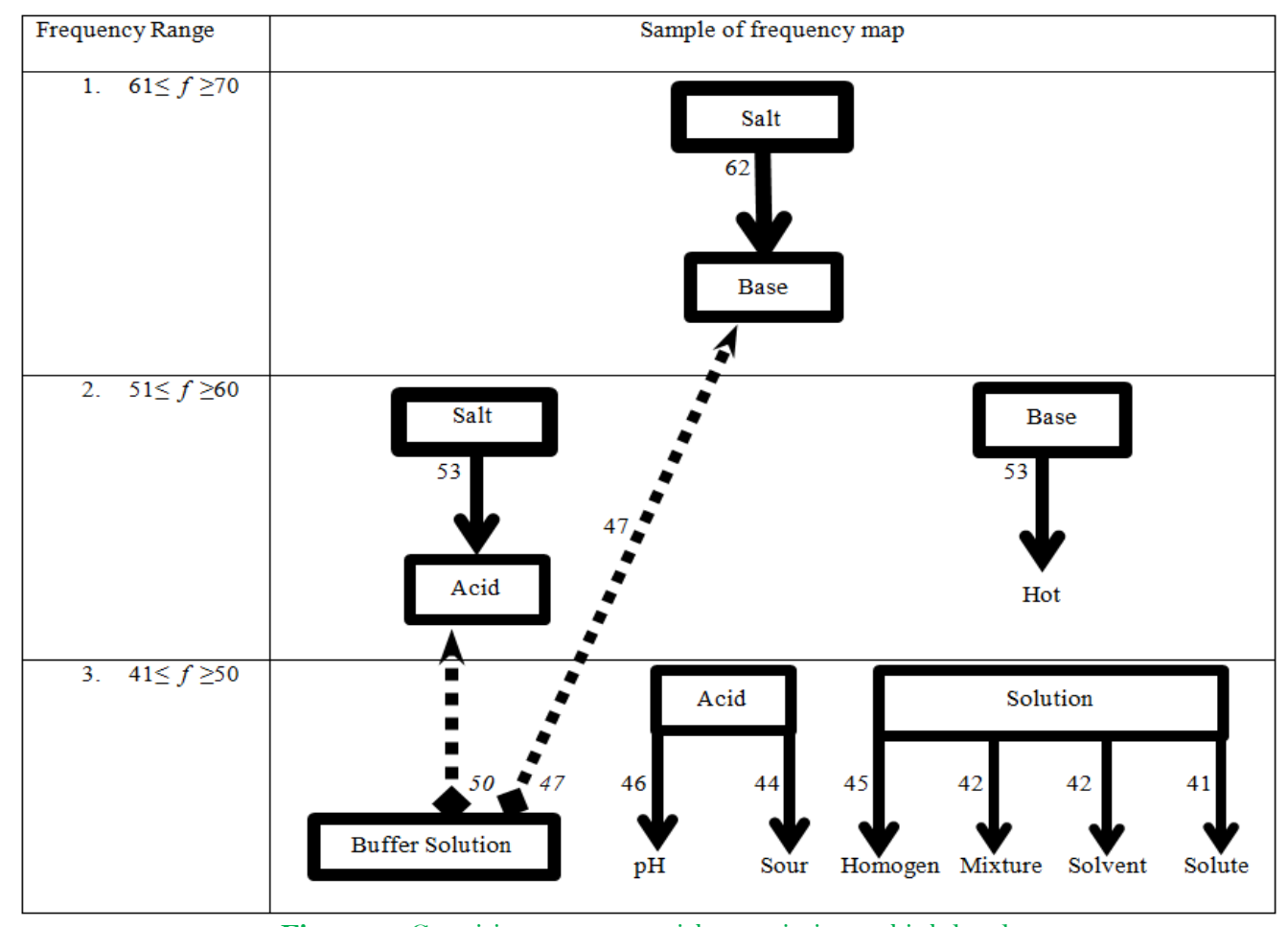

Figure-1. Cognitive structure with association at high level. 
The last stimulus word buffer solution is associated with the $\mathrm{pH}$ and salt. At the fifth, sixth and seventh level, all the stimulus words are associated with the response words. In this study, the data obtained through WAT was applied to find out the learning difficulties that the students experience when learning the subject of buffer solution.

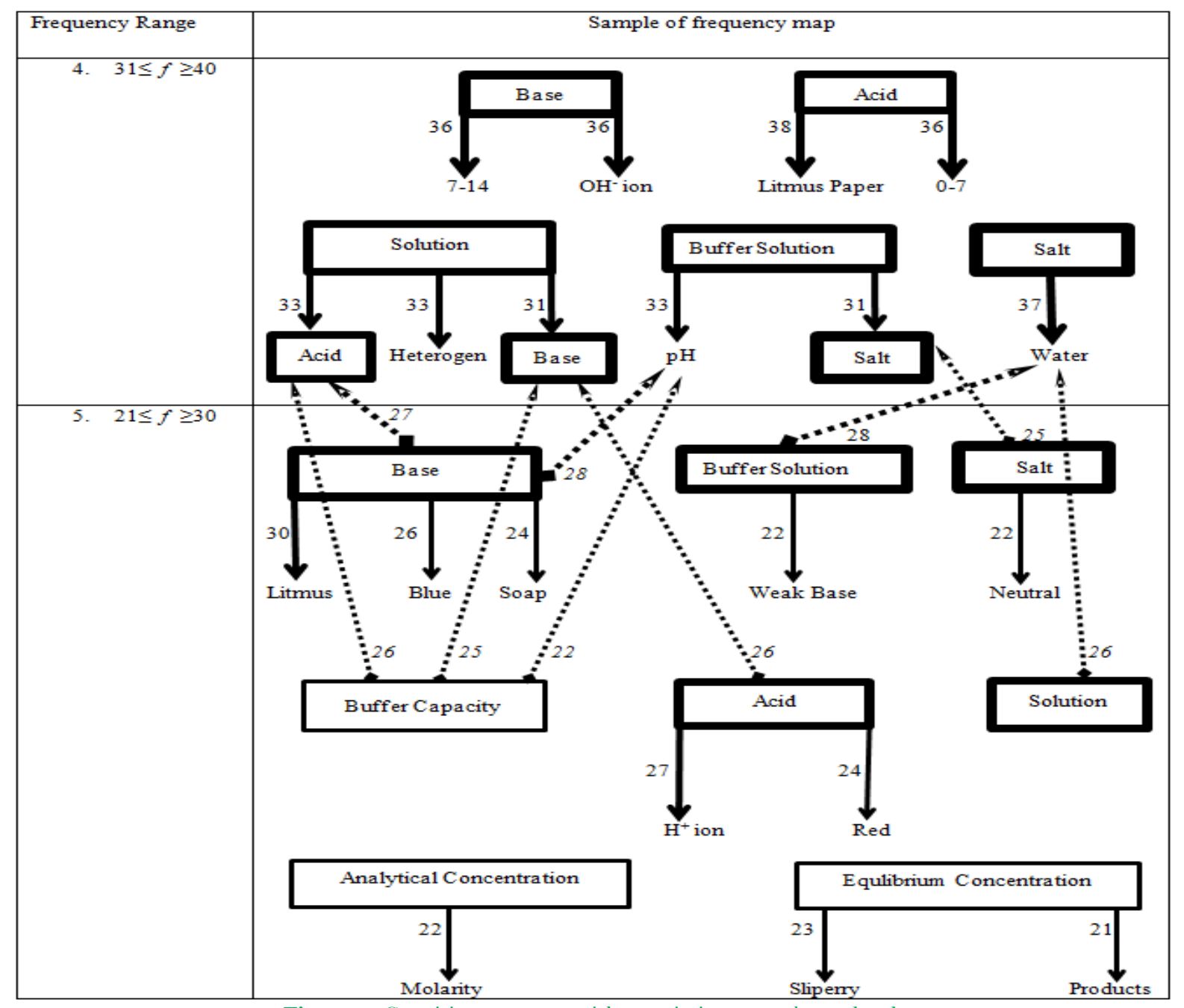

Figure-2. Cognitive structure with association at moderate level.

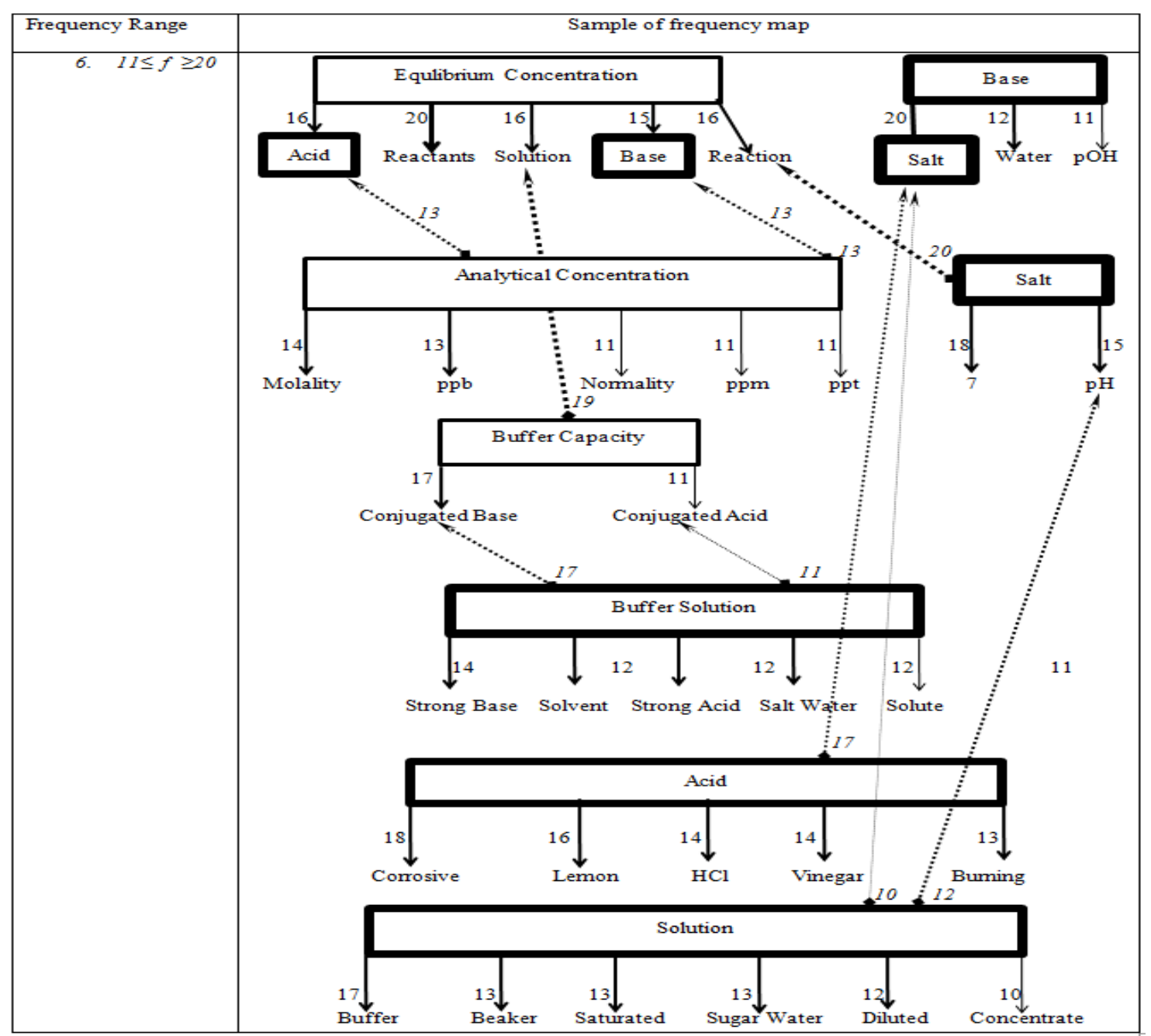




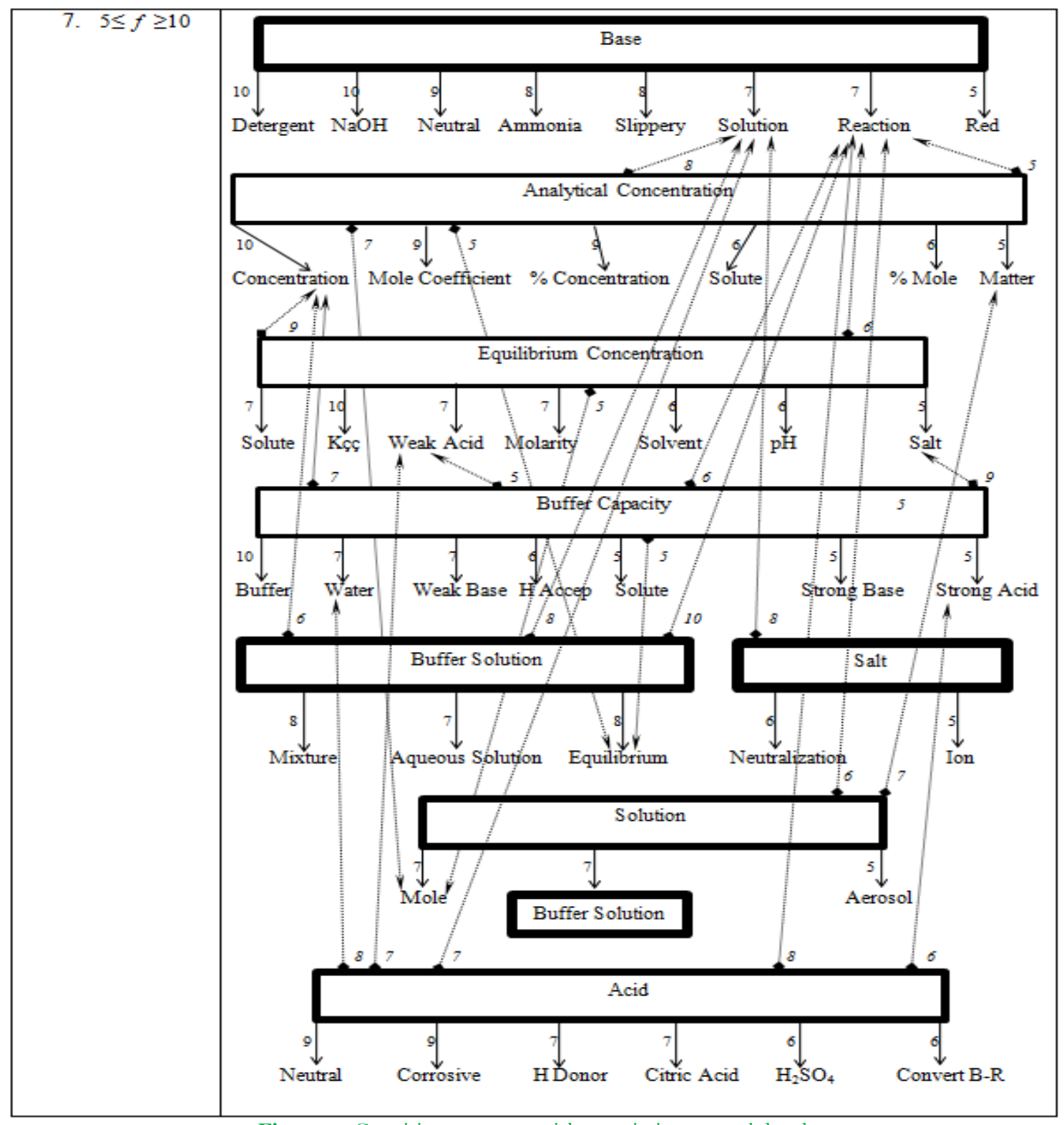

Figure-3. Cognitive structure with association at weak level.

\section{Discussion and Conclusion}

The solution chemistry should be well understood since it is prerequisite of concept of buffer solution. The stimulus words salt has the highest number association (62) with the response word base. At the high level of the frequency map only the stimulus words salt, base, buffer solution, acid and solution appeared to be associated with the response words base, acid, $\mathrm{pH}$, sour, hot, homogeneous, mixture solvent and solute. This strong connection shows that cognitive structure of the participants about the concept of solution is well developed. According to constructive learning approach because of the associations with former experiences, the existing mental structure affects the individuals' perception of new information and the cognitive structure that they will build (Anderson, 1992). From this survey, it is expected that the same development do exist on the concept of buffer solution. For the stimulus word "buffer solution", the expected response words at the highest level of frequency are weak and conjugated acid and base, maintain $\mathrm{pH}$, analytical concentration. Only weak base response word is associated 22 times with the stimulus word buffer solution at the moderate level of frequency. At the low level of frequency, the response words conjugated acid and base, are associated 19 and 15 times with the same stimulus word respectively. In the $61 \leq f \geq 70$ frequency range only the stimulus Word "salt" is associated with the response word base. This may show a powerful relation or well developed structure about the acid-base chemistry which is also related but not directly about the buffer solution chemistry. In the $51 \leq f \geq 60$ frequency range only two stimulus words salt and base have association. Both the stimulus words salt and base are associated with the response words acid and hot 53 times. Having repeated of these words at this frequency level also supports the idea of strong relation or well developed structure about acid-base chemistry. However the response word hot is not in the scientific definition of the science education curriculum. This relation most likely comes from the given example during learning process in science or chemistry courses at the middle and high school level. Science or chemistry teachers generally exemplify the acid as sour and base as hot in order to facilitate the acid-base concepts and make connection with the real life. In the $41 \leq f \geq 50$ frequency range, only three stimulus words are present. These words are buffer solution, acid and solution the stimulus word buffer solution is associated with acid 50 times and with base 47 times. The stimulus word acid is associated with $\mathrm{pH} 46$ times and with sour 44 times. The high association of the response word sour with acid also supports the idea of exemplifying the word acid as a sour at the former classes. The stimulus word solution is associated with the response words homogeneous 44 times, mixture 42 times, solvent 42 times and solute 41 times. This high frequency implies that foreknowledge of the solution chemistry is well structured in the students' minds. Up to this frequency level less interactive connections came into view.

At the moderate level, five stimulus words (salt, base, acid, solution and buffer solution) appears in the $31 \leq f \geq 40$ frequency range. At this level no response words are interconnected with any of these five stimulus words and thus, we can conclude there is no interconnection on the base of buffer solution at this level. The result of having 
difficulties in networking the individual's knowledge can be deduced from this view. As the response frequency decreases the number of emerged stimulus words increases. Within the $21 \leq f \geq 30,11 \leq f \geq 20$ and $5 \leq f \geq 10$ frequency range all the stimulus words appeared. Although we observed that the weakest frequency range exist within these level, cognitive networking is well-developed when compared to the higher frequency level. At the undergraduate level, science students are expected to have structural characteristic of association about the topic of buffer solution. For well-developed cognitive structure, it is important to have a dynamic and multiple ways of connections. However; the multiple ways of connections of the stimulus word should be with the right response word. At this academic level, students are expected to have a well-developed cognitive structure to understand the topic of buffer solution soundly. From this survey, although, a dynamic, multiple ways of connections within the $11 \leq f \geq 20$ and $5 \leq f \geq 10$ frequency range, exist, little meaningful association appears with the proper response words. Related with the topic of buffer solution, the cognitive structure of PSTs is weak and one directional at the higher level of frequency. At this level, the strength of the association is quite high (62). As we go down the lower level frequency, the association networking becomes high and multi-directional. However; the strength of the association appears to be very low. The author can suggest at this point, the chemistry and science teachers at the former level of the college can provide a sound concept definition and right examples with the right response words during the process of teaching of buffer solution as a topic. In addition to this, the chemistry textbook writers can use a well-designed materials and activities (experiments, pictures including macroscopic, microscopic and multi-particle modelling) in their textbooks (Adadan, 2014). Since meaningful chemistry education should structure the coordinated manner of macro, micro and symbolic level of chemistry knowledge (Talanquer, 2011). Thus, students are able to have a well-developed cognitive structure, multi-directional and a high strength of connections in their minds.

\section{References}

Adadan, E., 2014. Investigating the influence of pre-service chemistry teachers' understanding of the particle nature of matter on their conceptual understanding of solution Chemistry. Chemistry Education Research and Practice, 15(2): 219-238.Available at: https://doi.org/10.1039/c4rpoooo2a.

Anderson, O.R., 1992. Some interrelationships between constructivist models of learning and current neurobiological theory, with implications for science education. Journal of Research in Science Teaching, 29(10): 1037-1058.Available at: https://doi.org/10.1002/tea.3660291004.

Atasoy, B., 2004. Science learning and teaching. Ankara: Asil Publisher.

Aydın, F. and M.F. Taşar, 2010. An investigation of pre-sevis science teachers 'cognitive structures and ideas about the nature of technology. Ahi Evran University Kırşehir Faculty of Education Journal, 11 (4): 209-221.

Bahar, M. and M.H. Hansell, 2000. The relationship between some psychological factors and their effect on the performance of grid questions and word association tests. Educational Psychology, 20(3): 349-364.Available at: https://doi.org/10.1080/713663739.

Bodner, G.M., 1986. Contructivism: A theory of knowledge. Journal of Chemical Education, 63(10): 873-877.

Derman, A. and I. Eilks, 2016. Using a word association test for the assessment of high school students' cognitive structures on dissolution. Chemistry Education Research and Practice, 17(4): 902-913.Available at: https://doi.org/10.1039/c6rpo0084c.

Garner, B.K., 2007. Getting to got it: Helping the struggling students learn how to learn. Alexandria, VA, USA: Association for Supervision and Curriculum Development. pp: 1-30.

Gunstone, R.F., 1980. Word association and the description of cognitive structure. Research in Science Education, 10(1): 45-53.Available at: https://doi.org/10.1007/bfo2356308.

Johnson, P.E., 1967. Some psychological aspects of subject-matter structure. Journal of Education Psychology, 58(2): 75-83.Available at: https://doi.org/10.1037/h0024465.

Koseoglu, F. and E. Bayir, 2011. Examining cognitive structures of Chemistry teacher candidates about gravimetric analysis through word association test method. Trakya University Educational Faculty Journal, 1(1): 107-125.

Kurt, H. and G. Ekici, 2013. Determination of the cognitive structures of biology teacher candidates about the concept of $\mathrm{m}$ osmosis iyle by independent word association test and drawing-writing technique. Turkish Studies-International Periodical for the Languages, Literature and History of Turkish or Turkic, 8(12): 809-829.

Kurt, H. and G. Ekici, 2013a. To determine the cognitive structures and alternative concepts of biology teacher candidates about "bacteria. Turkish Studies-International Periodical for the Languages, Literature and History of Turkish or Turkic, 8(8): 885-910.

Mervis, C.B. and E. Rosch, 1981. Categorization of natural objects. Annual Review of Psychology, 32(1): 89-115.

Nakiboglu, C., 2008. Using word associations for assessing non major science students' knowledge structure before and after general Chemistry instruction: The case of atomic structure. Chemistry Education Research and Practice, 9(4): 309-322.Available at: https://doi.org/10.1039/b818466f.

Novak, J.D. and D.B. Govin, 1984. Learning how to learn. Newyork: Cambridge University Press.

Posner, G.J., K.A. Strike, P.W. Hewson and W.A. Gertzog, 1982. Accommodation of a scientific conception: Toward a theory of conceptual change. Science Education, 66(2): 211-227.Available at: https://doi.org/10.1002/sce.3730660207.

Schizas, D., E. Katrana and G. Stamou, 2013. Introducing network analysis into science education: Methodological research examining secondary school students' understanding of" decomposition. International Journal of Environmental and Science Education, 8(1): $175-198$.

Shavelson, R.J., 1972. Some aspects of the correspondence between content structure and cognitive structure in physics instruction. Journal of Educational Psychology, 63(3): 225-234.Available at: https://doi.org/10.1037/ho032652.

Talanquer, V., 2011. Macro, submicro, and symbolic: The many faces of the Chemistry "triplet. International Journal of Science Education, 33(2): 179-195.Available at: https://doi.org/10.1080/09500690903386435.

Uzuntiryaki, E. and Ö. Geban, 2005. Effect of conceptual change approach accompanied with concept mapping on understanding of solution concepts. Instructional Science, 33(4): 311-339.Available at: https://doi.org/10.1007/s1 1251-005-2812-z. 